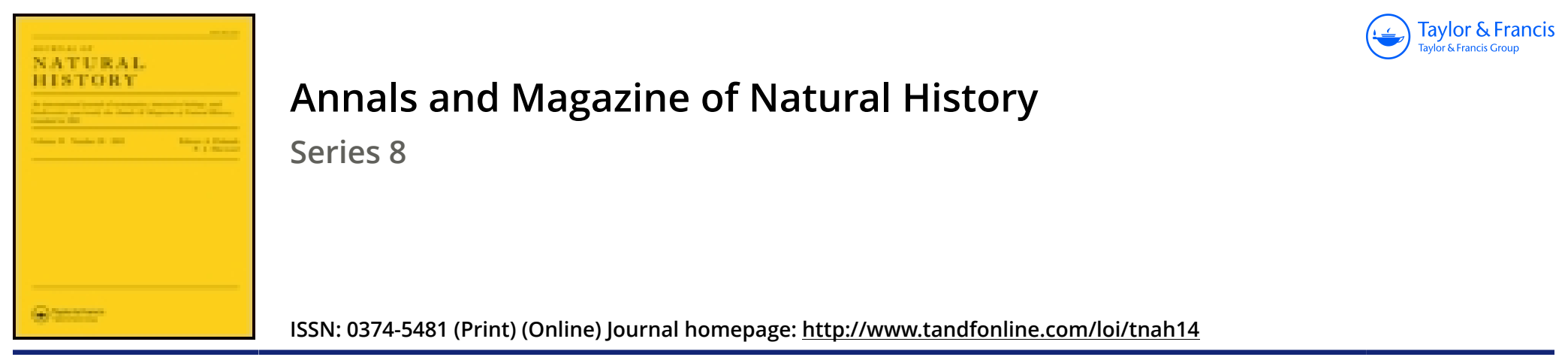

\title{
LIII.-Notes on the Apidæ (Hymenoptera) in the collection of the British Museum, with descriptions of new species
}

\section{Geoffrey Meade-Waldo M.A.}

To cite this article: Geoffrey Meade-Waldo M.A. (1916) LIII.-Notes on the Apidæ (Hymenoptera) in the collection of the British Museum, with descriptions of new species, Annals and Magazine of Natural History, 17:102, 448-470, DOI: 10.1080/00222931608693811

To link to this article: http://dx.doi.org/10.1080/00222931608693811

曲 Published online: 11 Sep 2009.

Submit your article to this journal $\pi$

Џll Article views: 2

Q View related articles $\square$

Citing articles: 3 View citing articles ๘ 
Subfamily NITELINE.

Nitela rufiventris, sp. $\mathrm{n}$.

․ Nigra; mandibulis, scapo, flagello articulis duobus basalibus, tegulis, abdomine pedibusque rufo-ferrugineis; alis hyalinis, iridescentibus, venis testaceis, stigmate radioque nigris. Long. $3.5 \mathrm{~mm}$.

9. Clypeus not strongly convex, without a distinct carina. Eyes strongly divergent towards the clypens, separated on the vertex by a distance equal to the length of the two basal joints of the flagellum. Head finely and closely punctured, the front thinly clothed with short pale golden pubescence; posterior ocelli almost touching the eyes. Pronotum nearly as long as the scutellum, not sunk below the mesonotum, the margins only very slightly raised, so that the usual transverse sulcus is not well defined. Mesonotum closely and finely punctured, with a row of larger punctures before the scutellum, which is almost smooth. Median segment coarsely longitudinally striated, rounded at the apical angles, the posterior slope more finely transversely striated. Abdomen smooth and shining. Legs unarmed.

Hab. Monkey Bay, Lake Nyasa, June (W.A. Lamborn).

The neuration is as in typical Nitela, but the species is easily recognized by the colour.

LIII.-Notes on the Apidæ (Hymenoptera) in the Collection of the British Mnseum, with Descriptions of new Species. By Geoffrey Meade-Waldo, M.A.*

(Published by permission of the Trustees of the British Museum.)

VII.

THE following notes and descriptions were prepared during the recent rearrangement of the collection of Apidr in the Museum.

Much valuable information on the type-specimens \&c. contained in the British Musoum has already been published by Professor Cockerell, who had studied them during a

* [We deeply regret the death of our valued contributor Mr. G. MeadeWaldo, who passed away on the 11th of March at the early age of 32 . The proof of this paper, which he sent to the 'Annals' shortly before his death, has been kindly corrected by Mr. R. E. Turner.-Ens, 'Annals.'] 
hurried visit to Europe a few years since. I have here attempted to fill in certain gaps which were left by him, doubtless owing to lack of time; thus, nothing much has appeared on the Ethiopian species of Halictus and Nomia, the species of which, described by Frederick Smith and other authors, are here tabulated.

The notes on Bombus have been gone through by Dr. Franklin, of Massachusetts, who may make further use of them.

The types of all new species are in the British Museum.

\section{Subfamily ANDRENINZI.}

Halictus vinctus (Walker).

Nomia vineta, Walk. Ann. \& Mag. Nat. Hist. (3) v. p. 305 (1860). q. Ceylon.

Halictus kalutara, Ckll. l.c. (8) viii. p. 189 (1911). ․ Ceylon.

An examination of Walker's type in the British Museum proves this species is a Halictus. Bingham suggests this in the 'Fauna of India,' but does not seem to have examined the type, which was among the rest of Walker's Cingalese types in a separate cabinet apart from the main general collection, and thus likely to be overlooked by students. Cockerell, as is only natural, did not consider Walker's species of Nomia when studying the Indian and Cingalese Halictus of the Comber Collection. It has already been shown by Cockerell (Trans. Amer. Ent. Soc. xxxvii. p. 218, 1911) that Andrena exagens, Walker, also from Ceylon, is a Nomia.

Halictus albofasciatus, Smith.

Halictus albofasciatus, Smith, Descr. New Spec. Hymen. p. 33 (1879). ‥

Paranomia broomi, Cam. ? MS.

\section{Halictus jucundus, Smith.}

Halictus jucundus, Smith, Catal. Hymen. Brit. Mus. i. p. 56 (1853). of $q$.

Halictus atroviridis, Cam. (pars.) Trans. S. Afr. Phil. Soc. xvi. p. 325 (1906). ㅇ.

In the British Museum there are four specimens from the Cameron Collection labelled as "types" of $H$.atroviridis by Cameron himself, and two species certainly are represented. One individual of $8 \frac{1}{2} \mathrm{~mm}$. in length is nothing but $H \cdot j u$ cundus, Smith. The measurements given by Cameron $(3-5 \mathrm{~mm}$.) point to the smaller specimens being the real 
types of $H$. atroviridis, which species, however, must become a synonym of $H$. cethiopieus, Cam. (vide infra).

\section{Halictus athiopicus, Cam.}

Halictus athiopicus, Cam. Trans. S. Afr. Phil. Soc. xv, p. 239 (1905). Halictus atroviridis, Cam. l. c. xvi. p. 325 (1906),

Both these species were described from Pearston, Cape Colony, and the types of both are in the British Museum.

\section{Key to Ethiopian Halictus in the British Museum.}

\section{오오.}

1. (8) Abdominal tergites with pale tegumentary fascix.

2. (5) Larger, more robust species, the fasciæ

rather broad. Length $10-12 \mathrm{~mm}$.

3. (4) Face clothed with griseous pubescence. Length $12 \mathrm{~mm} . . . . . . .$. albofasciatus, Smith.

[(S. Africa.) (= Paranomia broomi, Cam.)

4. (3) Face clothed with smoky pubescence.

5. (2) Smaller, more slender species, the fasciæ linear. Length $7-8 \mathrm{~mm}$.

6. (7) Tergites 1-4 with narrow apical fascir [Kirby. (Socotra.)
favovittatus, W. F.
[('Transval.)
albolineolus, Cam.

7. (6) Tergites 1-5 with narrow white fascix ................... [(Transvaal.) vittatus, Smith. (Cape [of Good Hope.)

H. tricolor (Cam.), H. nomioides, Friese, and its var. grandior, Friese, come in here.

8. (1) Abdominal tergites with pubescent

9. (10) Tegument brassy green, pubescence pale yellow ................ [Africa.)

$H$. niloticus, Smith, from the White Nile, is a male with brassy-green tegument.

10. (9) Tegument black, some segments at least with griseous fascim.

11. (24) Larger species. Length at least $9 \mathrm{~mm}$.

12. (13) Clypeus apically truncate, with a distinct tooth on each side at apex; tergites 1 and 2 with interrupted apical fascice of pale pubescence; hind calcar toothed, Length $10 \mathrm{~mm}$. (Cape of Good Hope.) .........

13. (12) Clypeus without any teeth at apex; tergites 1 and 2 at least with com-

deceptus, Smith. plete fascire of pale pubescence; hind calcar toothed or not.

14. (15) Hind calcar with three teeth; tergites $2-5$ with pale fasciæ. Length $10 \mathrm{~mm}$. (Natal.) ............ diversus, Smith. 
15. (14) Hind calcar unarwed.

16. (17) Scopa on outer side of tibia darkhaired; tergites 1 and 2 basally with griseous pubescence. Length $11 \mathrm{~mm}$. (S. Africa.) .......... rufomarginatus, Smith.

17. (16) Tibial scopa pale-huired; all the tergites with griseous pubescence.

18. (21) Tegument of hind legs black.

19. (20) The base of tergites 1-4 clothed with griseous pubescence; a robust species. (Cape Colony.) ........

20. (19) Tergites with only inconspicuous apical fasciz; a slender species. Length $9 \mathrm{~mm}$. (S. Africa.) ......

21. (18) Tegument of bind tarsi at least pale.

22. (23) Tegument of hind legs entirely honeyyellow .....................

23. (22) Hind tarsi honey-yellow .........

24. (11) Smaller species. $7 \mathrm{~mm}$. and less.

25. (26) Tegument of posterior tibiæ ferruginous. Length $7 \mathrm{~mm}$. (S. Africa.)

26. (25) Tegument of posterior tibix black. Length $6 \mathrm{~mm}$. (Sierra Leone.)..

capicolus, Cam.

communis, Smith.

[(Transvaal. $)$

latibalteata, $\mathrm{Cam}$.

rubricaudis, Cam.

terminalis, Smith.

iridipennis, Smith.

\section{of 0.}

Halictus frontalis is the only male described by Smith. It is a larger species than any of the females, with the exception of $H$.rufomarginatus.

\section{Halictus (Corynura) chilensis, Spin.}

Halictus chilensis, Spin., Gay, Hist. fis. Chile, Zool. vi. 1851, p. 201. no. 1. 옹․

Corynura flavofasciata, Spin., Gay, l. c. p. 302. 0 .

Cacosoma marginatum, Smith, Descr. New Spec. Hymen. p. 41 (1879). o.

Alfken has shown (Deut. ent. Zeit. 1913, p. 325) that Corynura gayi, Spin., is the male of $H$. rubellus, Haliday. Spinola seems to have forgotten that he described the male of $H$. chilensis when describing C. flavofasciata later on in the same volume, for they are certainly co-specific.

\section{Megalopta, Smith (1853). ('Type M. bituberculata, Smith.)}

=Sphecodogastra, Ashm. (1899). Type: Parasphecodes texana (Cress.). =Subgenus Megaloptidia, Ckll. (1900). Type: M. contradicta, Ckll. o. =Subgenus Megaloptella, Schrottky (1906). Type: Halictus ochrias (Vach. 1904).

$=$ Halicti megalopti, Vach. (1904).

I cannot agree with those authors who sink this welldefined group of Nearctic species to Halictus, a genus already far too large for convenience. The size of the ocelii affords an easily recognized and constant structural character. 
Ducke (Zeitschr. wiss. Ins. Biol, i. p. 175, 1905) treats of the nocturnal habits of $M$. idalia. The same author, who examined the types of Brazilian bees described by Smith (Dent. ent. Zeit. p. 363, 1910), leaves only $R$. idetia in the genus, relegating $M$. bituberculata, which was selected by Cockerell as the type (Proc. Phil. Acad, p. 374, 1900), to Halictus. Of the species described as Megalopta by Smith at later dates only $M$. purpurata (1879) can remain in the genus, and its inclusion is open to question ; the remaining species work out mainly as proposed by Ducke $\left(l, c_{.}\right), \theta_{.}$g., $M$. nigrofemorata and $M$. ianthina go in to Halictus sens. lat., while $M$. pilosa and $M$. cuprifrons belong to the cacosona group of species in that genus. $M$. ornata, a brilliant metallic-green insect, has nothing whatever to do with the genus, and probably needs a new one. M. vivas has quite rightly been placed as a variety of Augochlora atropos, Smith, though I do not agree with Ducke in synonymizing Augochlora with Halictus.

Key to the Species.

$$
\text { 우. }
$$

1. (2) Black species, non-metallie. Length $13 \mathrm{~mm} . . . \ldots \ldots \ldots \ldots \ldots \ldots . . . . .$.

2. (1) Testaceous species, head and thorax with some metallic iridescence.

3. (4) Cheeks armed with a conspicuous tubercle; clypeus much broader than long. Length $15 \mathrm{~mm} . \ldots \ldots$ genalis, sp. $\mathrm{n}$.

4. (3) Cheeks unarmed.

5. (8) Enclosed area well developed; hind spur with six well-developed spines.

6. (7) Joint 3 of antennes longer than 4, as long as 5. Length $17 \mathrm{~mm}$. ......

7. (6) Joint 3 of antenna short, not longer than 4. Length $14 \mathrm{~mm}$. ........

8. (5) Enclosed area very narrow, hardly cherazon, Vach. (1904). more than linear; hind spur with four spines.

9. (10) Postscutellum almost as long as scutellum, clypeus only sparsely punctured .................. chaperi, Vaeh. (1904).

10. (9) Pastscutellum only half as long as scutellum, clypeus coarsely punctured. idalia, Smith (1853).

M. cuprea, Friese (1911), is possibly a variety of $M$. idalia.

$0^{\circ} 0^{\circ}$

1. (4) Black species.

2. (3) Thorax and abdomen with faint coppery and purple iridescence. [= virgili, Fr. (1911). Length $14 \mathrm{~mm}$. ............ purpurata, Smith (1879) 
3. (2) Face and pleura sometimes faintly blue. Length 9-11 $\mathrm{mm} . . . \ldots \ldots$.

4. (1) Testaceous species; head and thorax mostly with a coppery iridescence; abdomen, as a rule, testaceous.

5. (6) Scutellum bituberculate. Length 11 mm. ....................

6. (5) Scutellum unarmed,

7. (12) Sternite 3, at least at base, without any longitudinal sulcus.

8. (11) Sternite 3 entirely testaceous.

9. (10) First recurrent nervure interstitial with second transverse cubital ner-

10. (9) First recurrent nervure received about

contradicta, Ckll. (1900) [ type of subgenus [Megaloptidia).

bituberculata, Smith [(1853) (type of genus).

idalia, Smith (1853).

argoides, Vach. (1904). ochrias, Vach. (1904)

11. (8) Sternite 3 black at base ...............

12. (7) Sternite 3 with longitudinal sulcus to its extreme base.

13. (14) Postscutellum as large or almost as large as scutellum ............

14. (13) Postscutellum shorter than scutellum.

[(type of subgenus $\mathrm{Me}$ [galoptella, Schr.).

agis, Vach. (1904).

athantis, Vach. (1904).

M. texana (Cress. 1872), from Texas, and M. (Megaloptella) ipomoce, Schrottky (1912), are omitted from the above. Further points of difference between the Vachalian species will be found in his key (Miscell. Ent. p. 113, 1904).

\section{Megalopta genalis, sp. $\mathrm{n}$.}

9. Capite thoraceque viridi-cupreis, nitentibus, abdomine pedibusque testaceis, omnino plerumque aureo-hirtis ; capite maximo, thorace latiori, genis gibbosis, utrinque infra tuberculatis; mandibulis falciformibus; alis subhyalinis.

Long. $15 \mathrm{~mm}$.

Head for the most part and thorax greenish bronze; antennæe, clypeus at apex, mandibles (except apically), labrum, tegulæ, abdomen, and legs testaceous; the whole covered with pale golden pilosity, that on the ventral scopa longer. Head very massive, rather broader than the thorax, the genæ much swollen, produced below to form a conspicuous tubercle; eyes slightly emarginate, inner orbits converging above but parallel below; no malar space; ocelli large, forming a triangle, clypeus twice as broad as long, depressed towards the apex, the apical margin raised; labrum shining, depressed, with a median process; mandibles falciform, bidentate, the outer tooth projecting considerably beyond the inner. Joint 3 of antennæ hardly longer than joint 4 . Basal area of median segment about half postscutellum in length, of equal width transversely, the middle with a longitudinal keel and striæ, colour of chitin a deep purple. Abdomen 
with basal segment of a paler testaceous than the apical segment. Posterior tibiæ and metatarsi of equal length, hind calcar with four spines. Head, thorax, and abdomen finely and evenly punctured, the legs coarsely punctured.

Wings subhyaline, slightly smoky.

Length $15 \mathrm{~mm}$.

Panama: Bugaba (Godman-Salvin Coll., G. C. Champion), 1 \% .

This fine species is easily recognized by the swollen tuberculate genæ.

\section{Nomia, Latr.}

Some corrections are necessary in the synonymy of this genus and its subgenera, owing to the wrong species having been selected as type. The traditional view was that $N$. diversipes, Latr., was the type, whereas the true type is N. curvipes (Fabr.), as selected by Bingham ("Fauna Brit. India,' i. p. 447) Ashmead (1899) and Cockerell (1910) both adopted $N$. diversipes as type.

I am inclined to follow Cockerell in regarding Nomia as a single genus including several named subgenera. Paranomia, Friese, would contain N. curvipes, the type of the genus, and thus becomes Nomia, sens. str.

Nomia, Latreille, Hist. Nat. Crust. Ins. xiii. p. 369 (1805). Type Andrena curvipes, Fabr. (1781).

=Subgen. Paranomia, Friese, Festsehr. d. Ver. Schles. Insektenkunde in Breslau, p. 48 (1897). Type: N. chalybeata, Smith.

$=$ Pseudapis, W. F. Kirby, Bull. Liverp. Mus. iii. p. 16 (1900). Type: P. anomala, W. F. Kirby.

=Subgen. Steganomus, Rits. Tijdschr. v. Ent. xvi. p. 224 (1873). Type : S. javanus, Ritsema.

=Subgen. Cyathocera, Smith, Trans. Ent. Soc. Lond. 1875, p. 47. Type: $C$ nodicornis, Smith.

$=$ Subgen. Crocisaspidia, Ashm. Trans. Amer. Ent. Soc. xxvi. p. 68 (1899). Type: N. scutellaris, Sauss. = C. chandleri, Ashm. (1899).

=Subgen. Hoplonomia, Ashm. J. N. York Ent. Soc. xii. p. 4 (1904).

Type: H. quadrifasciata, Ashm.

=Subgen. Stictonomia, Cam. Records Albany Mus, i. p. 192 (1905). Type: S. punctata, Cam.

=Subgen. Meganomia, Ckll. Ann. \& Mag. Nat. Hist. (8) iv. p. 402 (1909). Type : $N$. (M.) binghami, Ckll.

I have made a key to the Ethiopian species of Nomia of which the types are in the British Museum. Of some species there are large series, and in these cases several localities have been given as an aid to distribution, the type-locality being followed by a " $t$." 
An interesting new species of the subgenus Meganomia is described below.

Key to Ethiopian Nomia in the British Museum.

1. (4) Tegulæ enlarged.

$$
\text { 우오. }
$$

2. (3) Tegument black and red, median segment evenly punctured; wings clear hyaline. Length $10 \mathrm{~mm}$. ..

3. (2) Tegument black, median segment basally impunctate, dull; wings subbyaline, more fuscous towards

4. (1) Tegulæ normal. apex. Length $8 \mathrm{~mm} . \quad . . \ldots \ldots$.

5. (6) Tegument of abdomen red, with some black markings basally. Length

6. (5) Tegument of abdomen otherwise

nilotica, Smith. (White

[Nile, t.)

tegnlata, Smith. (Sierra

[Leone, t.; Durban.)

fausta, Smith. (Natal,

7. (8) Abdomen with broad apical tegumentary fasciæ, yellowish white; facial pubescence whitish. Length $9 \mathrm{~mm} . . . \ldots \ldots \ldots \ldots \ldots \ldots$ candida, Smith. (Sierra Leone, t., Lagos (Strachan); Salisbury (G. A.K. Marshall); Nyasaland (Neave, Stannus); British East Africa (Neave, R. C. Wood); Abyssinia, Harrar (Kristensen).)

8. (7) Abdomen with pubescent fasciæ, face with fulvous-golden pubescence.

9. (10) Apices of tergites only laterally pubescent; wings clear hyaline : a small slender species. Length $6 \mathrm{~mm} . .$. .

10. (9) Tergites $2-5$ with broad apical fasciæ of golden pubescence; wings slightly aurifrons, Smith. (Si[erra Leone, t.) fuscous : a larger, more robust species. Length $10 \mathrm{~mm}$. ........ fulvohirta, Smith. (Sierra Leone, t., Lagos (J.A. de Gaye).)

\section{0 .}

1. (2) Tegulæ enlarged; black, abdomen very coarsely punctured, with pale pubescent fascix. Length $8 \mathrm{~mm}$....... anomala (W. F. Kirby). (Socotra, t., Mozambique, and Durban (Muir), ơ 우 N. Rhodesia (Silverlock), ơ of Abyssinia,

2. (1) Tegulæ normal. Harrar (Kristensen).)

3. (8) Tegument of abdomen for the most part red.

4. (5) Hind legs simple, not swollen, the tibiæ conspicuously serrate on the outer side; wings subfuscous, the basal half paler. Length $9 \mathrm{~mm}$. .. serratula, Smith. (Na-

5. (4) Hind legs abnormally swollen. tal, t., Nyasaland (Neave).)

6. (7) Wings dark fuscous; hind tibir 
without any lamellar process at apex; terminal joint of flagellum normal. Length $11 \mathrm{~mm} . . . . \ldots$ rubella, Smith $=$ pulchritarsis, Cam. (Gambia, t., Lake Nyasa, Port. E. Afr. (Neave), ơ $q$; Natal (Cregoe); Transvaal (t. of pulchritarsis).)

7. (6) Wings light fuscous, darker towards apex; hind tibix with a lamellar process on the inner side; terminal flagellar joint spatulate, basally constricted. Length $13 \mathrm{~mm} . . . . \ldots$ strenua, Cam. (Transvaal, t., Port. E. Afr., and Nyasaland (Neave); Matabeleland ( $D r . H$. Swale).)

8. (3) Tegument of abdomen mostly dark ; hind legs simple, not swollen.

9. (10) Wings hyaline, the tip very markedly fuscous. Length $10 \mathrm{~mm} . .$. nubecula, Smith. (Sierra Leone, t., Uganda (Gowdey, W. P, Lowe Neave), 옹.)

10. (9) Wings unicolorous, hyaline or subhyaline.

11. (12) Larger: length $12 \mathrm{~mm}$. Apical segment with two small teeth ..... testacea (Smith).

12. (11) Smaller: about $7 \mathrm{~mm}$. No apical
[("Africa," t.) teeth.

13. (14) Comparatively stout species; the abdomen with tegumentary fascix; scutellum with two blunt tubercles; frontal pubescence whitish ..... rufitarsis, Smith. (Angola, t., $\delta$; Nyasaland (Neave), ơ $q$; Matabeleland (Sivale).)

14. (13) Slender species; abdominal fascir not tegumentary.

15. (16) Frontal pubescence golden; postscutellum covered with dense pale pubescence; stigma and nervures pale testaceous ............... cinerascens, Westw. (Natal, t., Durban (Muir) ; Nyasaland (Neave); Transvaal (t. of leviannulatus).)

16. (15) Frontal pubescence whitish ; postscutellum bare; stigma and nervures dark $\ldots \ldots \ldots \ldots \ldots \ldots$ clavata, Smith. (Sierra

17. (18) Anterior tarsi flattened, lamellate, [Leone, t., N. Nigeria (Macfie).) ivory-white ; frontal pubescence golden; abdomen parallel-sided. Length $10 \mathrm{~mm}$. .............. patellifera, Westw. (Cape of Good Hope, t., Durban (Muir); Matabeleland (Swale), $\delta$; ; Nyasaland, German East Africa (Neave).)

18. (17) Anterior tarsi simple, not lamellate; species with tegumentary or pubescent fasciæ on abdomen.

19. (22) Mesonotum almost bare of pubescence; legs entirely red.

20. (21) Tergites 3 and 4 with very coarso rugose punctures along the apical 
margin; bind femora subtubercu-

late. Length $10 \mathrm{~mm} . . . . . . . . .$.

Colony Willowmon dalyana, Cam. (Cape Colony; Willowmore (Brauns); Transvaal (Cholmeley).)

21. (20) Tergites evenly punctured all over ; a distinct tooth on outer surface of hind femora. Length $8 \mathrm{~mm}$. .... rufipes, Smith. (Gam-
[bia, t.)

22. (19) Mesonotum densely clothed with velvety pubescence; legs yellow

dalyana, Cam. (Cape (Brauns); Transval and black.

23. (24) Hind femora armed with three sharp teeth below. Length $9 \mathrm{~mm}$. .... tridentata, Smith $=$ erudelis, Westw. (West Africa, t., N. Nigeria (ScottMacfie, Simpson) ; Mashonaland (G.A. K. Marshall).)

24. (23) Hind femora with only one sharp tooth. Length $11 \mathrm{~mm}$.

25. (26) Abdominal fasciæ griseous; wings fuscous at apex ............. jansei, Cam. (Trnns-

26. (25) Abdominal fasciæ golden; wings hyaline to apex ............ armatula (Smith). (Sierra Leone, t., N. Nigeria (Simpson).)

\section{Nomia (Meganomia) andersoni, sp. n.}

3. Nigra; facie prothoraceque flaro-maculatis, plus minusve griseo-hirsutis, tergitibus 1-7 fasciis interruptis flavis; flagello serrato ; femoribus posticis incrassatis; alis hyalinis.

Long. $18 \mathrm{~mm}$.

Head and thorax black; mandibles (except apex), clypeus, the inner orbits to above insertion of antennæ, a small line behind each eye, scape beneath, four marks on prothorax in front $\backslash)(/$, tubercles, tegulæ in front, and axillæ yellow; mandibles at apex, flagellum beneath, and tegulæ behind ferruginous. Abdomen : tergites $1-7$ black, with yellow fascia widely interrupted in middle and widening abruptly towards the sides ; sternites 1-3 yellow except for three pairs of black spots, the remaining sternites black. Legs : anterior coxæ, trochanters, and femora mostly black; tibra and tarsi yellow, the tarsi with a conspicuous fringe of black hairs on the inner side ; middle legs yellow ; posterior legs about equally black and yellow, the tarsi almost entirely black. Clypeus apically truncate, with a narrow, median, quadrate tooth ; joints 4-10 of flagellum subtuberculate beneath, the three terminal joints slender, forming a hook. Hind femora greatly thickened, a distinct carina along the inner side; hind tibiæ more or less flattened, convex, widening gradually towards apex, the upper margin carinate, the apex with a blunt lamellate tubercle on the lower edge; 
hind tarsi slightly arched and grooved along the inner margin. The area behind the eye, the thorax (except mesonotum and scutellum), abdomen, and legs more or less clothed with griseous pubescence; hind tarsi with black pubescence on the inner side. Wings hyaline.

Length $18 \mathrm{~mm}$.

British East Africa : Masai Reserve, 14. iv. 1913 (T. J. Anderson), 1 ot. Received through the Imperial Bureau of Entomology.

I have pleasure in naming this fine species after the donor and captor, Mr. T. J. Anderson, Government Entomologist, British East Africa.

In general appearance this species strongly resembles Anthidium florentinum, Latr. The subgenus Meganomia, Ckll. (Ann. \& Mag. Nat. Hist. (8) iv. p. 402, 1909), hitherto contained only one species, $N$. (Meganomia) binghami, Ckll. (l.c.), of which both sexes are described from Damaraland. 'The following differences seem to justify the description of the East-African species as distinct :-

N. (Meganomia) binghami, Ckll.

Tergites 2-6 with unbroken yellow fascix.

Clypeus at apex $\neg-\widetilde{c}$.

Flagellum not serrate.

Hind trochanters pointed bohind.

Hind tibia with a hump on middle of inner side.
N. (Meganomia) andersoni, sp. $\mathbf{n}$.

Tergites 2-6 with yellow fasciæ widely interrupted in middle.

Clypens at apex $\square$.

Flagellum serrate.

Hind trochanters not pointed behind.

Hind tibiæ with no such hump.

Nomia viridicincta, sp. $\mathrm{n}$.

ㅇ. Nigra, nitida; capite thoraceque sat dense pilosis; segmentis 1-4 apice fasciis viridibus ; alis subhyalinis.

Long. $12-13 \mathrm{~mm}$.

Black, head and mesonotum rather densely clothed with a mixture of fulvous and black hairs, sternum and truncation of median segment clothed with pale fulvous hair; first abdominal segment at base with conspicuous fulvous hair, the following eegments very scantily clothed with similar hair, and some longer adpressed black hairs. The legs black, scopa on hind legs mostly pale, but black on the outer side. $\mathrm{W}$ ings subhyaline, but with a distinct fuscons tinge. Abdomen shining black, segments 1-4 with apical green tegumentary fascix of even width, the intensity of green varying much in individual specimens.

Clypeus convex, apically truncate; head narrower than 
the thorax, which is massive; scutellum separated by a transverse groove from postscutellum, tegulæ normal, basal area of median segment almost obsolete, truncation of median segment rounded laterally.

Head and thorax rather coarsely punctured, the abdomen more finely, the apex of segments impunctate, shining.

Length $12-13 \mathrm{~mm}$.

Uganda Protectorate: Entebbe, Sept. 1-11, 2 의 (type); W. shore of Victoria Nyanza, Buddn, $3700 \mathrm{ft}$, ix. 1911, 6 o 9 ; Seziwa River to Kampala, 3500-3750 ft., viii. 1911, 2 q (S.A. Neave). Sierra Leone : xii. 1912 (J. J. Simpson), 1 i .

Var. evanescens, nov., $q$, resembles the type except in the colour of the fasciæ of segments 1-4, which are without any tinge of green.

Nyasaland: Mlanje, v. 1913 ; S.W. of Lake Clilwa, i. 1914 (S. A. Neave). Many specimens.

This species is a Nomia sens. str., and appears to be the first species described from the mainland of Africa with green tegumentary fasciæ, though this group (iridescens, chalybeata, \&c.) is prominent in the Oriental region and occurs in Madagascar (N. viridalimbata, Sauss., 1892). From this latter species it differs in having the abdomen only finely punctate and the wings subhyaline (not distinctly fuscous).

\section{Nomia exagens (Walk.).}

Andrena exagens, Walker, Ann. \& Mag. Nat. Hist. (3) v. p. 305 (1860). 9. Ceylon.

Halictus timidus, Smith, Descr. New Spec. Hymen. p. 31 (1879). ㅇ․ Ceylon.

Nomia clavatus (Smith), $\delta$.

Described as a Halictus, but is a Nomia of the N. hyloooides group.

\section{Nomia aurifrons (Smith), q.}

This species was also described as a Halictus. The type is a $q$, not a $\delta$ as stated in the original description. It may possibly be the $q$ of $N$. clavatus.

Nomia fuscipennis, Smith, and N. terminata, Smith.

Bingham (Fauna Brit. Ind. i. p. 449) separates these two species on the presence or absence of a clypeal carina. I have examined the series of each species, and find this character valueless. $N$. fuscipennis (type) has a distinet 
carina, $N$. terminata (type) has none, though the whole long series has some indication of one. The two species are readily distinguished by the wings ; in $N$. terminata these are flavo-hyaline, only the apex fuscous, while in $N$. fuscipennis the whole costal area is fuscous. I have never seen an authentic specimen of $N$. fuscipenreis from British India, thongh Bingham gives Sikkim. All the specimens in the British Museum are from the type-locality, Sumatra.

Nomia (Hoplonomia) cuneata, Sauss. (1872).

This species, described from Madagascar, is a Hoplonomia.

Nomia candida, Smith.

Nomia candida, Smith, Trans. Ent. Soc. Lond. 1875, p. 68. Sierra Leone.

Nomia braunsiana, Friese, Sjöstedt's Kilimanj.-Meru Exped. viii. p. 124 (1908). E. Africa.

In his description Friese says of his species, "near candida, but without golden fascia on first abdominal segment." I have examined Smith's type of $N$. candida, and find it has no such fascia, but, like $N$. braunsiana, there is a little golden pubescence on the sides of the apical margin of the segment.

In the British Museum there are specimens from RHODEsia, Salisbury (G.A.K. Marshall), determined by Friese as N. braunsiana; Nrasaland, Lake Chilwa and Mlanje (S. A. Neave) ; Abrssinia, Harrar, v. 1911 (G. Kristensen).

Nomia cinerascens, Smith.

Nomia cinerascens, Smith, Trans. Ent. Soc. Lond, 1875, p. 66. o. Natal.

Halictus leviannulatus, Cam. ? MS. Transvaal.

Nomia borneana, Cam.

Nomia borneana, Cam. Journ. Straits Asiatic Soc. xxxvii. p. 115 (1902). Borneo.

Nomia erythropola, Cam. l. c. xliv. p. 157 (1905). Borneo.

Nomia (Crocisaspidia) zonaria, Walker.

Nomia zonaria, Walker, List of Hymen. in Egypt, p. 43 (1871). o . Arabia.

Nomia lamellata, Smith, Trans. Ent. Soc. Lond. 1875, p. 65. 우. Egypt.

Cockerell suggests the above synonymy (Ann. \& Mag. Nat. Hist. (8) v. p. 504, 1910). I have not seen N. vespoides, Walker $(l . c$.$) .$ 


\section{Nomia scutellata, Smith.}

Nomia scutellata, Smith, Trans. Ent. Soc. Lond. 1875, p. 45. + . Calcutta.

Nomia albofimbriata, Cam. Ann. \& Mng. Nat. Hist. (f) ix. p. 252 (1902). Q. Bengal.

? Nomia ustula, Okll. Trans. Amer. Ent. Soc. xxxvii. p. 231 (1911). d. Kandy, Ceylon.

$N$. ustula would almost certainly seem to be the male of $N$. scutellata; $N$. ardjuna, Ckll., is very close to it (vide Trans. Amer. Ent. Soc. p. 231, 1911).

Nomia antennata, Smith (1875), val. sykesiana, Westw.

In the Fauna of Brit. India, Hym. i. p. 454, Bingham places Nomia sykesiana, Westw., doubtfully as a synonym, having only one poor specimen on which to rely for his decision. 'There are now further specimens of $N$. sykesiana in the collection from Nasik and Malvi in the Bombay Presidency (Comber Coll.) determined by Cockerell ; they are fresh specimens and have the abdominal fasciæ of pubescence pale (not golden as in $N$. antennata). I agree with Bingham (loc. cit.) that there is no structural difference, but $N$. sykesicina may be considered a well-marked variety.

\section{Nomia bidiensis, Cam.}

Nomia bidiensis, Cam. Journ. Straits Asintic Soc. xliv. p. 166 (1905). ㅇ. Borneo.

Nomia bicarinata, Cam. ? MS. \&. Borneo.

A specimen bearing the latter name is identical with $N$. bidiensis, but no description seems to have been published.

Nomia (Hoplonomia) elliotii, Smith.

Nomia elliotii, Smith, Trans. Ent. Soc. Lond. 1875, p. 44. Madras.

Nomia curinata, Smith, l.c. p. 57, Ceylon.

These are certainly the same species; Smith omits any mention of the spinose postscutellum in his description of N. carinata.

$$
\text { Andrena eduardi, nom. nov. }
$$

Andrena nigra, E. Saunders (nec Prov.), Trans. Ent. Soc. Lond. 1908, p. 195.

Provancher described an Andrena nigra from Los Angeles in 1895 .

Ann. \& Mag. N. Hist. Ser. 8. Vol. xvii. 
Andrena juponica (Smith).

Nomia japonica, Smith, Trans. Ent. Suc. Lond. 1873, p. 201. . Japan.

A typical Andrena, described from Hiogo.

Subfamily MeLITTINE.

Neiitta harrieta (Bingh.), ơ.

Andrena harrieta, Bingh. Fauna Brit. Ind., Hymen. i. p. 446 (1897). P. Sikkim.

Melitta altissima, Ckll. Entomologist, xlïi. p. 240 (1910). \&. Tibet.

In a note following lis description (l. c.) Cockerell refers to an undescribed Meletta from the Himalayas shown him by Colonel Bingham; it is possible that this specimen may have been since described as Andrena harrielce.

While working through the residue of the Tibetan material I found eight male specimens of a Melilta captured at the same time and place (Gyangtse, vi. 1904) as the types of Cockerell's M. altissima, of which species at present only the female is known.

In addition to secondary sexual characters, the male differs as follows:-

Clypeus and whole front of head clothed with long, dense, silvery-white pilosity; thorax (except median segment) with a covering of pale fulvous hair; abdomen as in the $q$, but colour of pubescence less intense (? nore faded). Rather smaller, $12 \mathrm{~mm}$.

\section{Melitta anthophoroides, sp. $\mathrm{n}$.}

९. Nigra, hirsuta; abdominis segmentis 4-6; tibiis tarsisque plerumque fulvo-hirtis; elypeo carina mediana longitudinali; alis aurantiacis.

Long. $17 \mathrm{~mm}$.

Black, for the most part clothed with thick black pubescence; tergites 4 (apically), 5 and 6 wholly covered with fulvous pubescence, and sternites $2-5$ with apical fringes of a similar pubescence; all the tarsi and the intermediate and pusterior tibia densely covered with fulvous pubescence. Calcaria and tarsal ungues dull ferruginous. Clypeus coarsely punctured, with a distinct longitudinal carina; scape and first joint of flagelluin black, remainder of antennæe dull ferruginous; vertex and thorax wholly covered with close medium-sized punctures, scutellum and postscutellum clothed with long, rather sparse hairs; enclosed area of median 
segment impunctate, truncation of median segment very sparsely punctured, almost bare of pubescence. Abdomen very finely punctured all over except the apical margins of the tergites, which are shining and impunctate; terminal stemite pointed, shining, impunctate, longitudinally subcarinate. Tegulæ shining, piceous. Wings golden hyaline, the nervures pale; stigma of medium size; third cubital cell at least three times as long as second; first r. $n$. joining second cubital cell about the middle, second $r$. n. joining third cubital cell at end of second third; basal nervure feebly arched.

Length $17 \mathrm{~mm}$.

1 ․

Siknim: Lebong, $5000 \mathrm{ft.,}$ ix. 1908 (H. W. Lefroy), ex Coll. Agricultural Research Iustitute, Pusa, Bengal.

The superficial resemblance between this species and Anthophora (Habropoda) tainaricola, Strand, is very striking; the type-lucality of A. tiananicola is Formosa, bnt there are specimens from Assam in the B:itish Museum which certainly appear identical. Like the other Himalayan species of Melitta referred to above, the pubescence is much denser than in the well-known species from the Westem Palæarctic region, e. g. M. homorrhoidalis, leporina, \&c.

\section{Melitta arrogans (Smith).}

Andrena arrogans, Smith, Descr. New Spec. Hymen. p. 56 (1879). $q$.

This species comes very near $M$. turreri (Brauns), but the condition of Smith's type is too poor to say whether they are identical. There is a co-type of $M$. turneri in the British Museum.

\section{Colletes neglecta (Smith).}

Andrena neglecta, Smith (auc Dour..), Descr. New Spec. IIymen. p. 57 (1879). Q .

Andrena negligenda, D. T., nom. nov. (1896).

The single specimen in pror condition is evidently a Colletes. It seems doubtul whether typical Andrena occurs in the Ethiopian Region.

Sublanily PanURgIr.r.

Rhophitulus, Ducke.

Rhophitulus, Ducke, Zeitseirr. Iym. Dipt. vii. p. 366 (1907).

Ducke (Zool. Jahrb. p. 88,1912 ) snggests that this genus 
may be synonymous with Macrotera, Smith (1853), but retains it as distinct on differences in the comparative position of the ocelli. I have examined types in both genera concerned, and find no difference in the position of the ocelli. There is, however, another character quite sufficient to separate Rhophitulus from Macrotera, viz., the large stigma ; in both known species of Macrotera-M.bicolor, Smith (1853), and $M$. secunda, Ckll. (1904)-the stigma is small and linear.

CaLLiopsis, Smith.

Calliopsis andreniformis, Smith, Catal. Hymen. Brit. Mus. i. p. 128 (1853). 오.

Calliupsis favipes, Smith, l. c. p. 129, o.

These two insects were both described from specimens taken by Edward Doubleday in East Florida, and are certainly only the sexes of one species. In the British Museurn is a pair from N. Dakota (G.A. Stevens) presented by Prof. Cockerell ; the male agrees perfectly with C. favipes, Sinith. I am unable to trace C. Alavifrons, Smith, referred to by Cockerell (Trans. Amer. Ent. Soc. xxxi. p. 321, $1905)$, the type of which is recorded as being in the British Museum.

Panurgus venustus, Erichson.

Panurgus venustus, Erichs., Waltl. Reise d. Tirol \&c., P. 2, p. 106 (1835). $\delta$.

Panurgus moricei, Friese, Zeitschr. Hym. Dipt. p. 308 (1905). of $q$.

In the Edward Saunders Collection are $2 \delta \delta$ and $2 q q$ identitied as Erichson's species, no doubt correctly. Mr. Morice has presented a pair of co-types of $P$. moricei, Fr.; this species is described from the sane series as those labelled $P$. venustus by Saunders ; all were captured by Mr. Morice in the same locality on the same day, namely, Jimena, Andalusia, i. v. 1905, Friese places P. venustus in Camptopceum. Mr. Morice agrees with me in this synonymy, and says that he thinks Friese has noticed it himself ; but I am unable to find a record of it.

\section{Subfamily XYLOCOPINA.}

XYlocopa, Latr.

A study of more material of the ccerulea group of species, this time kindly submitted for examination by Mr. J. C. Moulton, Curator of the Sarawak Museum, has led to some 
interesting discoveries. Typical $X$. (Koptorthosoma) caruleiformis, M.-Waldo (Ann. \& Mag. Nat. Hist. (8) xiv. p. 454, 1914), is well represented in both sexes; but there is one specimen-a female-in which the brilliant azure pubescence is replaced with fulvous brown, similar in colour to that of the male. The female is doubtless dimorphic, the phenomenon of dimorphism being already well known in the African species $X$. caffra, L., and $X$. inconstans, Smith.

Xylocopa (Koptorthosoma) caruleiformis, M.-Waldo, var. fusca, nov.

?. Formæ typicæ omnino similis, sed capite, thorace segmentoque primo abdominis brunneo-hirtis.

SarawaK: Matang, March 2, 1904.

To the type-locality (Matang) may be added the following localities in Sarawak :-Kucling, March 1900, Feb. 1901, of o ; Limbang, April 1910. Other localities for the species are Singapore and Mt. Kinabulu (B. N. Borneo), $3000 \mathrm{ft}$., 30. ix. 1918 (J. C. Moulton), 市.

$X$. (Koptorthosoma) corulea, Fabr., is represented by a series of $7 q q$ and $1 \delta$ from various Bornean localities; there are also 2 o $q$ from Singapore.

Sarawak : Trusan, A ug. 1900. British North Borneo: Kinabalu, Sept. 1913, 4 q 1 o (J. C. Moulton).

In this species, too, the female is apparently dimorphic, one form, as in the preceding species, having the pubescence coloured as in the $\delta$.

Xylocopa (Koptorthosoma) carulea, Fabr., var. viridis, nov.

․ Formæ ţpicæ similis, sed capite, thorace segmentoque primo abdominis viridi-hirtis.

SarawaK : Kuching, 11. ii. 1908 (G. Meade-Waldo), 2 \% (type) ; Lawas, ix. 1909, 1 \% (co-type in Sar. Mus.). This variety was first considered by me to be the $q$ of $X$. malayana (=sarawakensis, Cam., as which it is recorded, Sarawak Museum Journal, no. 3, p. 24, 1913), but the female of that magnificent species still awaits discovery.

\section{$X$ Xlocopa matangce, sp. n.}

․ Nigra, viridi-ænea, nitida ; capite fulvo-, thorace tergiteque primo pallide flaro-pilosis; tergitibus $2-4$ apice lateribus albofasciatis, pedibus nigro-hirtis; alis subfuscis.

Long. $18 \mathrm{~mm}$. 
Head black, thorax and abdomen dark greenish bronze, shining; head with dark hair on vertex, cheeks with a whitish pile, the whole thorax above and tergite 1 clothed with a pale vellowish pubesconce, tergites $2-4$ with pale hair linterally at apex, tergites 5 and 6 fringed with dark hair. The legs entirely black. Wings with three cubital cells, subliyaline, the apical area suffused with fuscons.

Head closely and evenly punctured, thrat on thorax and abdomen shallower: malar space very short, impunctate, enclosed area of median segment impunctate. Clypeus flat, truncate, with a very small median tooth, sides of clypeus forming two little pits at the junction with face. A pical sternite with a longitudinal carina.

Jength $18 \mathrm{~mm}$.

SarawaK: Mt. Matang, 10. ii. 1914 (G. E. Bryant), type; Matang Road, iii. 1909 (J. E. A. Lewis), and "Matang," iii. 1904, co-types. The last-mentioned specimen in the Sarawak Museum.

The receipt of more material has enabled me to describe this species, which I referred to in an earlier paper (Ann. \& Mag. Nat. Hist. (8) xiv. p. 455, 1914). It belongs to $X y$ locopa sens. str., and appears to be most closely related to $X$. collaris, Lep., from which, however, it can be readily distinguished by the colour of the pubescence.

\section{Subfamily BoMBIN}

Bombus nasutus, Smith.

Bombus nasutus, Smith, Trans. Eut. Soc. Lond. ser. ii. 1852, vol. ii. p. $44 . \zeta$.

Bombus breviceps, Smith, $l$. $c$.

A careful examination of the types convinces me that these two are co-specific, $B$. breviceps being a smaller individual. Sinith notes their relationship, but adds, "the form of the head is decisive of their difference." I am unable to find any difference. Both were captured at Chusan.

These species, together with $B$. diversus, Snith, from Japan, and B. opulentus, Smilh, from N. China, both somewhat similar in appearance, have been misunderstood by recent authorities. In Dalla Torre's Catalogue $B$. nasutus is given as a synonym of $B$. melunurus, Lep. (altaicus, Er.), doubtless on the authority of Handlirsch (Ann. Naturh. Hofnus. iii. p. 213, 1888), and B. opulentus is considered synonymous with $B$. breviceps (1. c.).

These species may be separated by the fullowing characters: they are all richly clothed with bright golden- 
yellow hair on the thorax and basal tergites, the apical tergites being clothed with black hair:-

1. (2) Malar epace short, ahout as long as broad at the apex; third joint of antenne ]$\frac{1}{2}$ as long as joint $4 \ldots \ldots \ldots \ldots$

2. (1) Malar space long, about twice as long as broad at apex; third joint about twice as long as joint 4 .

3. (4) Tergites 1-3 clothed with golden-yellow hair; wings fusco-hyaline ....... diversus, Smith.

4. (3) Tergites 1 and 2 (except laterilly) clothed with golden-yellow hair; wings dark fuscous ........... opulentus, Smith.

Friese considers $B$. diversus to be a variety of $B$. hortorum, subsp. ussurensis, Rad.

Bombus lapidarius, [., var. tunicatus, Smith.

Bombus tunicntus, Smith, Trans. Entom. Soc. Lond. 1852 (2), ii. pt. 2, p. 43, pl. viii. fig. 7 .

Bombus incertus, Norawitz, Bull. Acad. Sc. St. Pétersbourg, xxvii. p. $229(1881)$.

Authentic examples of $B$. incertus, Mor., from the Radoszkowski Collection differ in no way from typical B. turicatus, Smith. Sclımiedeknecht (A pil, Europ. p. 371, 1883) records this synonymy with a query. There seems little doubt that this is only a form of $B$. lapidarius, $\mathrm{L}$., as recorded by Dalla Torre in his Catalogue, by Friese (Ann. Mus. Zool. St. Pétersbourg, p. 518, 1905), and by Friese and Wagner(1910).

Bombus lapidarius, L., var, gilgitensis, Ckll.

Bumbus gilyitensis, Clll. Ann. \& Mag. Nat. Hist. (7) xwi. p. 223 (1905). 오.

This species was described from Gilgit, Kashmir. Cockerell notes the resemblance to $B$, tunicatus at the time, and later (Ann. \& Mag. Nat. Hist. (8) v. p. 417, 1910) is inclined to think it is a variety of it. I am of this opinion, and consider them brth (i. e., B. tunicatus and $B$. giligiensis) varieties of $B$. lapidarius. There are recently acquired specimens from Hunza, North Kashmir, 8000 ft., 3. ix. 1913 (R.W.G. Hingston) in the National Collection.

Bombus alienus, Smith.

Bombus alienus, Smith, Catal. Hym. Brit. Hus. ii, p. 402 (1854).

There is a specimen of this insert, which was described 
from North China, in the British Museum from Shillong, Assam, x. 1903 (R, E. Turner). The species is omitted from the 'Fauna of British India,' vol. i. (1897). Smith's original description is sufficiently good for colour; the malar space is rather longer than broad at apex, the third antennal joint is rather larger than the fourth.

This is probably the same species as $B$. vallestris, Smith (1878), described from the Second Yarkand Expedition ; but I have not seen the type.

Bombus longiceps, Smith.

See Cockerell (Ann.\& Mag. Nat. Hist. (8) v. p. 505, 1910) on this species. I agree with him that the Baltistan specimen cannot possibly be a form of $B$. hortorum. Unfortunately the type is not available, being in the same collestion as the previous species. The British Museum has recently received six $\nsucceq \nsucceq$ from Hunza, North Kashmir, viii. 1913 (R. W. G. Hingston).

Bombus bicoloratus, Smith (1879).

Cockerell ('Entomologist,' p. 101, 1911) has written a note on this Formosan species and the nearly related $B$. latissimus, Friese (1910), in which he gives both structural and colour differences.

\section{Bombus ardens, Smith (1879).}

This Japanese species is known only from males. The malar space is of medium length, rather longer than broad at apex; joints 3 and 4 of the antennæ are about equal. This may prove to be the male of $B$. muscorum, var. tersatus, Smith, also from Japan.

From a perusal of Dr. Franklin's valuable "Monograph of American Bombus" (Trans. A mer. Ent. Soc. 1913), it would appear that the majority of the types of species of that genus considered to be in the British Museum are not there. The explanation for this is that the late Colonel Bingham was unwilling to accept as the type any specimen not actually labelled with the word "type" by the author, with the result that species described by Frederick Smith, which are certainly the actual type-specimens, are stated to be untraceable. 
Unfortunately there are also instances in which specimens distinctly labelled with the word "type" have been overJooked, and consequently inaccurate data supplied to Dr. Franklin.

\section{Species North of Mexico.}

Bombus polaris, Curtis (1831). The type $f$ is in the British Museum labelled " $B$, polaris, Curtis. Type from Curtis," in Frederick Smitl's handwriting.

Bombus arcticus, Kirby (1821). Type $q$ in British Museum, labelled "arcticus" in Kirby's handwriting.

Bombus frigidus, Smith (1854). The o type of this species is clearly labelled as such, with the word "type." Kirhy's misidentified $B$. derhamellus cannot be traced.

\section{Species South of the United States.}

Bombus trinominatus, Dalla Torre $(1890)=B$. modestus, Smith (1861) (nec Cresson, nec Eversman). Smith's type is in the British Museum.

Bombus formosus, Smith $(1854)=B$. pulcher, Cress. (1863). This species is erroneously recorded from "India" in Catal. Brit. Mus., but this locality is changed by Smith himself in the British Museum copy to "Mexico, Oajaca." The type-specimen from this locality is marked as "type" by Smith, and there can be no doubt that $B$. pulcher, Cress., is synonymous.

Bombus nigrodorsalis, Franklin $(1907)=B$. laboriosus, Smith (nec Fabr.). Smith's type $q$ is in the British Museum, and agrees in every respect with specimens of $B$. nigrodorsalis named by Dr. Franklin himself. Franklin tells me (in litt.) that he now considers nigrodorsalis and montezumo, Ckll., to be colour-variants of the same species.

Bombus thoracicus, Sichel $(1862)=B$. bellicosus, Smith (1879) $=B$. emilia, Della 'Torre (1890). Snith's species was quite naturally a source of difficulty to Dr. Franklin, owing to its locality being given as "Sumatra or India." The type-specimen bears no locality-details on the label, 
and the Asiatic locality published with the description is certainly wrong.

Bombus mexicanus, Cress. $(1878)=B$. unifasciatus, Smith (1879). The type $\Varangle$ of $B$. unifasciatus is marked with the word "type" by Smith himself, and the other specimens are unmistakably the types of the other castes.

Bombus diligens, Smith $(1861)=B$. brachycephalus, Handlirsch (1888).

LIV. - New Species of the Genus Platamops, Reitt. [=Spithobates, Champ.] (Coleoptera), from Tropical South America. By G. C. Champlon, F.Z.S.

The genus Platamops, including two species from Colombia, was described by Reitter * (1878) as a Cucujid, and said to have simple, 5-jointed tarsi, with a feebly lobel third joint. There can be no doubt, however, from the other characters given, that his definition of the tarsi was inaccurate (possibly he did not examine the posterior pair, or they were missing in his types), and that Platamops is synonymous with the Pythid-genus Spithobates, Champ. $\dagger(1889)$, also based upon two Tropical American forms. The four species now added, one from Colombia and three from Brazil, are all contained in the British Mnseum. These insects lave the tarsi 5-, 5-, 4-jointed in both sexes, and the ante-penultimate joint a litile stouter than the minnte penultimate one; the anterior coxal cavities open behind; the prothorax with four or five setigerons tubencles along the lateral margin; and the elytra clothed with intermixed long, erect, tactile seta and decumbent hairs. The general facies is very like that of the Cucujid genera Telephanus and Cryptamorpha, and this doubtless deceived the Austrian author, who compared Platamops with Platamus, Fr., and Parabrontes, Redr., whereas the affirity with the Pythid-genus Salpingus, Gyll. (Sphoriestes, Steph.), is obvious. The species here described have six of the outer antemual joints widened, as in the P. (Sy,ithobates) sttosus, Champ., from Chiriqui, the three terminal joints only being thickened in the Central American

* Verh. zuol.-bot. Ges. Wien, xxvii. p. 177 (187t, issued in 1878).

F Biol. Centr.-Am., Coleopt. iv. 2. p. $10+$ (1889). 